\title{
9 \\ Quality Matters: A Faculty-Centred Program to Assure Quality in Online Course Design
}

\author{
Kay Shattuck \\ Quality Matters Programs, USA
}

One of the dilemmas faced by today's faculty is assuring quality in online courses. As one solution to that dilemma, Quality Matters (QM), a program of MarylandOnline, built a rubric of design standards informed by existing research literature and best practices. The rubric was implemented within a faculty-centred, peer review process in which colleagues share their expertise to facilitate course design improvements and to achieve an established level of quality in online course design. This article will describe the basic tenets and processes of QM as an inter-institutional quality assurance program for online learning.

\section{Introduction}

$\mathrm{Q}$

uality in online courses need not be caught in the riptides that can result from the continuing waves of educational refocusing. While online learning might appear to be a new wave, it is not. It has become the most accepted form of distance education, bringing along with it legions of faculty inexperienced in designing and teaching in distance formats. That was the dilemma faced in the early 2000s by members of MarylandOnline (www.marylandonline.org), a voluntary consortium of community colleges and universities in Maryland.

A definition of distance education seems in order. Moore and Kearsley's (1996, 2005) widely cited definition points out that distance education is much more than piping traditional classroom courses through a communication conduit, such as the Internet. In fact, they define distance education as "planned learning that normally occurs in a different place from teaching, requiring special course design and instruction techniques, communication through various technologies, and special organizational and administrative arrangements" (2005, p. 2). It is a system of education focused on enabling and supporting selected learner-teacher, learner-content, and learner-learner interactions via a communication technology (Moore, 1989).

Attempts to assure and record quality in distance education have a long history. Distance education has been documented by Russell (2001) as 
far back as 1928 as not being significantly different than education delivered in traditional classroombased settings. Russell assembled and continues to post research findings on the http://nosignificantdifference.org, website, including no significant differences in performance on graded assignments, final course grades, and other assessments of learning. It can be noted that some studies indicated significance in favor of either face-to-face or at a distance, but most indicated similar results when the two delivery formats were compared.

Recently, the US Department of Education (2009) conducted a meta-analysis of existing research on the effectiveness of online learning. The final report noted that, "on average, students in online learning conditions performed better than those receiving face-to-face instruction." It was further noted that students in "blended conditions" (combining online and face-to-face) benefitted the most because of "additional learning time and instructional elements" (p. ix). The meta-analysis methodology used was limited to studies using random-assignment or controlled quasi-experimental design in web-based instruction. Only studies that examined "objective measures of student learning" were included in the final meta-analysis. Studies which focused "on student or teacher perceptions of learning or course quality" for example, were not included in the analysis (p. xii). The report cautioned "in generalizing to the K-12 population" since the 44 studies that met the study criteria came from adult learning settings, such as higher education or medical training (p. xii).

\section{Quality Matters}

As online formats were beginning their meteoric rise in popularity at the turn of the millennium, members of MarylandOnline faced the dilemma of assuring faculty of the quality of shared online courses. Course sharing and collaboration amongst consortium member community colleges, four-year colleges, and universities across the state of Maryland had been the motivation for organizing MarylandOnline in the mid-1990s.

As sharing of online courses became popular, faculty of MarylandOnline member institutions expressed concern about determining the quality of an 'adopted' course from another institution. As a result, Quality Matters $(\mathrm{QM})^{1}$ was envisioned as an inter-institutional peer review process to improve the quality of online courses. Grant funding from the Fund for the Improvement of Postsecondary Education (FIPSE), a federal grant of the US Department of Education, allowed for development of the project from 2003-2006. Since 2006, the program continues to grow as a not-for-profit, subscription-based program and now includes more than 365 subscribing institutions across the US (and the University of Guelph in Canada). ${ }^{2}$

At the 2009 Society for Teaching and Learning in Higher Education conference in New Brunswick, Alex Lowry kicked off the discussion of dilemmas and problem-solving in today's education by presenting a $2 \times 2$ problem/solution dilemma matrix. While it is not the purpose of this article to critique QM's development from the Lowry model, I suggest that distance educator members of MarylandOnline envisioned a solution to the challenge of assuring quality in online courses. By using the work of leaders from research and best practices in the field, they developed a niche program focusing on course design and peer review for the improvement of online learning.

\section{The Quality Matters Rubric TM}

Course design - the forethought and planning of an online course - includes selection of learning objectives, technology and media options, instructional strategies, and evaluation techniques (Moore \& Kearsley, 2005; Shearer, 2007). Course design is one of many factors affecting online course quality. Other systemic factors include: course delivery (the way a course is taught); course content; the learning management system and its functionality (including

\footnotetext{
${ }^{1}$ For more information on the program, visit www.qualitymatters.org.

${ }^{2}$ For the complete list of institutions visit http://www.qualitymatters.org/Documents/Subscriber\%20List\%20for\%20Publication.pdf
} 
technical support); the institutional infrastructure (for example, help desk, online library access, online tutoring access); instructor training; and learner readiness. The developers of QM faced the complex dilemma of assuring a level of quality by keeping their focus on course design. A faculty-centred set of values promoting continuous quality improvement guided efforts for faculty to improve their own online courses (with help from instructional designer when available). The resulting peer process was to be guided by a set of standards that would become the QM Rubric ${ }^{\mathrm{TM}}$.

The QM Rubric ${ }^{\mathrm{TM}}$ was developed in its current format in 2004 during the FIPSE grant period. Design principles put forward by Chickering and Ehrmann (1996) and the American Council on Education's Guiding Principles for Distance Learning in a Learning Society (1996) and Distance Learning Evaluation Guide (2001) were piloted and consolidated (Shattuck, 2007). The aim was that the rubric would provide a practical definition and workable tool for determining a level of quality in online course design. The rubric was built upon best practices, existing distance education research, and instructional design principles (Sener \& Shattuck, 2006). ${ }^{3}$

The Rubric continues to be a living document that is reviewed and improved every two or three years following the same rigorous approach which has become the guiding principles of QM: collegial, collaborative, continuous, and centred in an academic foundation around student learning. For example, as a result of that process, the 20062008 version of the rubric added online components of blended courses.

The 2008-2010 version of the rubric includes eight general and 40 specific standards. ${ }^{4}$ The eight general standards include:

1. Course overview and introduction

2. Learning objectives

3. Assessment and measurement
4. Resources and materials

5. Learner engagement

6. Course technology

7. Learner support

8. Accessibility

Some examples of the standards include:

- Standard 1.1: Instructions make clear how to get started and where to find various course components.

- Standard 2.1: The course learning objectives describe outcomes that are measurable.

- Standard 3.1: The types of assessments selected measure the stated learning objectives and are consistent with course activities and resources.

- Standard 5.1: The learning activities promote the achievement of the stated learning objectives.

Each of the 40 standards has an assigned point value ( 3 =essential, 2 =very important, $1=$ important). An interactive rubric tool which includes annotations and other explanations to assist faculty reviewers during a review is available to QM subscribers.

Courses under review meet QM standards by attaining an overall 85\% score, including successfully meeting all of the 17 essential standards. The webbased, interactive rubric tool calculates and combines all scores and comments from the team. A detailed final report is presented directly to the faculty member whose course was reviewed.

\section{The Quality Matters Process}

The values of collegiality, collaboration, and academic foundations related to the impact of instructional

\footnotetext{
${ }^{3}$ Citations, resources, and referenced best practices can be found at http://www.qualitymatters.org/Documents/ Matrix\% 20 of $\% 20$ Research\%20Standards\%20FY0506.pdf

4 A listing of the 40 standards can be found at http:/qminstitute.org/home/Public\%20Library/About\%20QM/ RubricStandards2008-2010.pdf
} 
design on student learning are promoted by a course review process in which a faculty member seeks recommendations for improvement by a team of three online teaching peers who have received training on application of the QM Rubric ${ }^{\mathrm{TM}}$. The Rubric is a guideline to help experienced online instructors determine if a specific course meets QM standards. But, it is more than a review tool. The Rubric is part of a process in which peer reviewers make comments and recommendations for improvement of the course design. This can be considered from a constructivist lens as use of a set of guidelines by peers to guide discussion and offer recommendations to a colleague on specific course design improvements to enhance student learning.

Review teams are comprised of three members, including a subject matter expert (a faculty member who teaches in the same discipline as the course to be reviewed), a faculty member who is external to the institution which houses the course to be reviewed, and a QM master reviewer who chairs the review. The faculty member whose course is to be reviewed is also considered as an associate of the team. She or he provides initial information about the course and is encouraged to request focused attention on problematic areas in the course. Members of the review team are granted access to the online course and encouraged to advocate for students by taking a student view of the course. This is usually an enlightening experience for faculty who find themselves assuming a student perspective when entering and navigating an unfamiliar online course. Routinely, members of review teams comment on the benefits they gain from approaching an online course from a student's perspective while reviewing a peer's course.

The QM process is twofold: first, to make a decision on the current course design based on meeting QM quality standards; and second, to make comments and recommendations for improvement. A key activity of a QM review is the crafting of comments and recommendations by each team member as she or he looks for evidence for each of the 40 standards. Comments and recommendations for further improvement are to be made even when a standard is met at the QM threshold. The QM review process is not an evaluation of the teaching of the course, but a method of establishing and improving the quality of the design of the course. Evaluation of teaching is an institutional responsibility, not one for interinstitutional peer review.

The review team's recommendations are key to the success of a review. Commenting on the strengths of the course as well as the weaknesses is expected. Training prior to being certified as a QM peer reviewer emphasizes that recommendations should be constructive, specific, measurable, sensitive, and balanced in a professional, collegial fashion. For example, a recommendation is more collegial if written in the following way:

The learning objectives in unit 2 were well written - specific, measurable, etc. I did however have trouble connecting the assessments to the learning objectives in that unit. I think you'll want to review the learning objectives and make sure that they are reflected in the assessments.

This is more constructive and probably better received than commenting - "poor assessments" - to a professional colleague. All courses submitted for a QM review are expected to meet QM standards, either initially or upon revision. This confirms that the goal is for online faculty to assist peers in improving the design of their fully online or online components of blended courses.

\section{Summary}

In response to the challenges presented by the growth of online distance education and of emerging concerns of quality from faculty, QM, a faculty-focused program of peer review with the goal of improving course design of fully online and online components of blended courses, was developed as one solution. Built on the work of leaders in distance education in the form of existing distance education research, principles of instructional design, and best practices, the QM Rubric ${ }^{\mathrm{TM}}$ guides a team of faculty who teach online and have completed training in applying the 
rubric in a collegial manner to others' courses. Developed by visionaries as a regional solution to the dilemma of establishing quality assurance in online courses, the program finds a niche in addressing a dilemma shared by others. As a living set of tools and processes, QM provides some common language and standards for online faculty to improve and establish a level of quality in their own online courses.

\section{References}

American Council on Education. (2001). Distance learning evaluation guide. Washington, DC: Author.

American Council on Education. (1996). Guiding principles for distance learning in a learning society. Washington, DC: Author.

Chickering, A.W. \& Ehrmann, S.C. (1996). Implementing the seven principles: Technology as lever. Retrieved from http://www.tltgroup.org/ programs/seven.html

Lowry, A. (2009, June). Identify and management problems/dilemmas. Opening plenary at the Society for Teaching and Learning in Higher Education Conference, University of New Brunswick, Fredericton, New Brunswick, Canada.

Moore, M. G. (1989). Three types of interaction. The American Journal of Distance Education, 3(2), 1-6.

Moore, M. G. \& Kearsley, G. (1996). Distance education: A systems view. Belmont, CA: Wadsworth Publishing Company.

Moore, M. G. \& Kearsley, G. (2005). Distance education: A systems view ( $2^{\text {nd }}$ ed.). Belmont, CA: Wadsworth Publishing Company.

Russell, T.L. (2001). The no significant difference phenomenon: A comparative research annotated bibliography on technology for distance education: As reported in 355 research reports, summaries and papers ( $5^{\text {th }}$ ed.). Montgomery, AL: The International Distance Education Certification Center.

Sener, J. \& Shattuck, K. (2006). Research literature and standards sets support for Quality Matters review standards. Retrieved from http://www. qualitymatters.org/Documents/Matrix\%20 of $\% 20$ Research $\% 20$ Standards $\% 20 F Y 0506$. pdf

Shattuck, K. (2007). Quality Matters: Collaborative program planning at a state level. Online Journal of Distance Learning Administration, 10(3). Retrieved from http://www. westga. edu/ - distance/ojdla/fall103/shattuck 103. htm.

Shearer, R. (2007). Instructional design and the technologies: An overview. In M.G. Moore (Ed.), Handbook of distance education ( $2^{\text {nd }} \mathrm{ed}$.) (pp. 219-232). Mahwah, NJ: Lawrence Erlbaum Associates, Publishers.

US Department of Education. (2009). Evaluation of evidence-based practice in online learning: A meta-analysis and review of online learning studies. Retrieved from http://www.ed.gov/ rschstat/eval/tech/evidence-based-practices/ finalreport.pdf

\section{Biography}

Kay Shattuck has been active with Quality Matters since its inception and serves as the Director of Research. She received her Ph.D. from Pennsylvania State University and teaches online with their World Campus. 